\title{
LEGAL FICTIONS FOR ADMINISTRATIVE COURTS
}

Goal. The paper reveals features of applying administrative procedural legal fictions in order to avoid abuse of the right and evasion of the law when exercising procedural discretion.

Methods. For achievement of research purposes, the author uses special legal methods of scientific knowledge: formal-logical, system-functional, formal-logical, comparativelegal.

Results. Historiography of the legal fictions use has been dealt with. Essence of fictions has been highlighted in the paper as legal anomalies. The use of legal fictions in the administrative process has been detailed, taking into account the Grundnorm theory.

The connection between legal fictions and legal regulations has been revealed. The legal fiction has been described as a reinterpretation of the facts of an event in order to make these facts compatible with the rule, and at the same time allowing to get the correct result. This is a type of legal fiction-reinterpreting $X$ (or class $X$ ) as $Y$ in order to avoid an "inconvenient", unreliable, false, etc. result for the purposes of the law. As a rule, it is recognized that $X$ is not $Y$. That is, the court considers the creation of a fiction as a legitimate action within the framework of the judicial process; the activity that could be performed without concealment as a discretely true category.

Case law on the application of legal fictions has been described. It has been advised to use legal fictions when considering and resolving disputes, provided that there are false or clearly erroneous judgments in the provisions of existing applicable legal rules. As a consequence, time and resource costs for clarifying the facts of the case and over-motivating the judgment are minimized.

Conclusions. Firstly, features of legal fictions have been highlighted, in particular, for achieving the goals and objectives of administrative proceedings. Secondly, the classification of arguments, methods and approaches to the application of such atypical regulators in the administrative process has been proposed by the "meta" degree: 1) on the fundamental metric - internal, or zero-order arguments; 2) at the derivative definitive level - by defining functional, structural and relative concepts.

Key words: legal framework, tools, anomalies in law, atypical regulators, legal fictions, procedural discretion. 


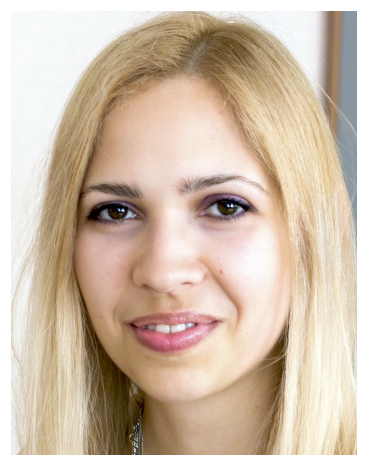

Anna Barikova, Legal Office (I) of Analytical and Legal Department of the Supreme Court, Chief Specialist National Academy of Internal Affairs, Academic Researcher, Ph.D. in Law orcid.org/0000-0002-9707-0106 anna.barikova@gmail.com

\section{Introduction}

Legal fictions play a leading role in shaping the boundaries of procedural discretion because they create an add-on to ensure the unity of law enforcement practices. It is worth noting that the basis for such a superstructure is the application by the administrative court of conflict-of-law rules and principles, valuation concepts and pre-emption categories.

The purpose of the paper is to reveal the features of applying administrative procedural legal fictions in order to avoid abuse of the right and evasion of the law when exercising procedural discretion.

The issue of applying administrative procedural legal fictions has been disclosed in the doctrine by such authors as S.S. Alekseev, V.K. Babaev, D.S. Gudz, A.Y. Ivanskyi, V.M. Kosovych, E.Yu. Marohin, D.I. Mejer, M.A. Pavlova, I.A. Shchukina, T.M. Suprun, O.S. Tkachuk, O.V. Ulianovska, O.V.Zhazhina, etal.At the same time, application of such atypical regulators in the administrative process remains insufficiently studied.

\section{Historiography of the application of legal fictions}

It is necessary to illustrate the directions and prospects for the use of legal fictions in the administrative proceedings implementation. In explanatory dictionaries, the term "fiction" (from lat.fictio-invention) is defined as non-conforming, absent; figment, forgery ${ }^{1}$. As a general rule, researchers also support this approach. In particular, O.V. Zhazhina interprets fiction as devise; a technique for summing up reality under a conditional formula ${ }^{2}$. The historiography of the formation and development of legal fictions shows that these categories were considered as anomalies and deviations in law and order, as well as methods for achieving consensus and "reconciliation" between dogmatic, conservative legal thinking and the real needs of social and legal life.

${ }^{1}$ Shchukina, I.A. (2012). Modern explanatory dictionary of the Ukrainian language. Donetsk: LLC "VKF "BAO", p. 882 [Щукіна I.A. Сучасний тлумачний словник української мови. Донецьк : ТОВ «ВКФ “БАО”», 2012. 960 с.].

${ }^{2}$ Zhazhina, O.V. (1999). Presumptions and fictions in law. Formation and development of scientific law schools at state universities of Russia: materials of the All-Russian student scientific and practical conference, Saint Petersburg, April 29-30, 1999. Saint Petersburg, part 3, pp. 18-22 [Жажина О.В. Презумпции и фикции в праве. Становление и развитие научных школ права в государственных университетах России : материалы Всероссийской студенческой научно-практической конференции, г. Санкт-Петербург, 29-30 апреля 1999 г. СанктПетербург, 1999. Ч. 3. С. 18-22]. 
Actually, the history of the legal fictions formation as a legal category began from the time of Ancient Rome. It refers to the power of judicial magistrates (praetors) to provide judicial protection under circumstances not established by the provisions of law in the manner of issuing an edict on actions with fiction ${ }^{3}$. At that time, the fictions did not cover the institutions of substantive law, although they did concern the protection of the rights, freedoms and legitimate interests of the citizens of the Roman Empire in the violation, nonrecognition or denial. That is, primarily legal fictions were procedural in nature.

In the Middle Ages, the substantive content of the legal category of fictions expanded. Legal fictions began to apply to the substantive legal institute of a legal entity. It was intended to establish the delinquency of cities as corporations - a set of residentsburghers as a whole with the competence of a legal entity ${ }^{4}$. During this historical period, legal fictions made it possible to reduce the imperative nature of medieval law by taking perceptions and images as actual acts that were not, or could not be, actually.

As an example, the use of fictions in English law allowed to mitigate the cruelty of criminal penalties for the deaths of persons found guilty of felony (any serious crime). Initially, a clergy privilege was applied which, as a result of expanding the list of court orders, began to apply to all first-time accused of a serious crime if they could read a wellknown Bible passage in Psalm (Psalm 51, verse 1) $)^{5}$. The foregoing means that legal fictions have a mixed (substantive) nature. This allowed the court to resolve substantive disputes not envisaged in the list of court orders. Judges were also empowered to interpret broadly the common law rules on the jurisdiction of cases to ensure the pragmatically coloured interests of litigants and judges. In particular, the salaries of judges were directly dependent on the number of cases examined. The expansive interpretation of the list of cases to be tried provided for an increase in the amount of the judge's remuneration. At the same time, this provided the basis for a broader protection of the interests of the parties to the case, given their increased access to justice.

In the future, until the XIX century, the evolution of the category of legal fictions took place in a progressive direction to establish a normative law and order. Thus, according to professor Demelius, fictions were considered as rules of law regarding the regulation of the actual relationship in order to equate the latter with a legally normalized standard ${ }^{6}$. However, fictions were not widespread in continental law at the time. The approach to the rationality of order under the law as a national-level legal phenomenon was dominant. In fact, positive law formed the basis of law enforcement practice.

\footnotetext{
${ }^{3}$ Mejer, D.I. (2003). About legal fictions and assumptions, about hidden and pretended actions. Moscow: Status, pp. 102, 341 [Мейер Д.И. О юридических вымыслах и предположениях, о скрытых и притворных действиях. Москва : Статус, 2003. 426 с.].

${ }^{4}$ Barihin, A.B. (compl.) (2000). Great legal encyclopaedic dictionary. Moscow: INFRA-M, pp. 405 [Большой юридический энциклопедический словарь / сост. А.Б. Барихин. Москва : ИНФРА-М, 2000. 719 с.].

${ }^{5}$ Suprun, T.M. (2013). Legal presumptions and related concepts. Bulletin of the Ministry of Justice of Ukraine, no. 2, pp. 125-132 [Супрун Т.М. Правові презумпції та суміжні поняття. Бюлетень Міністерства юстииії України. 2013. № 2. С. 125-132].

${ }^{6}$ Ulianovska, O.V. (2011). Stages of formation and development of scientific views on the nature and role of legal fictions. Law of Ukraine, no. 3, pp. 208-211 [Уляновська О.В. Етапи становлення та розвитку наукових поглядів на природу і роль правових фікцій. Право Украӥни. 2011. № 3. С. 208-211].
} 
It should be clarified that in the pre-revolutionary law of Eastern Europe, A.M. Gulyaev, G.F. Shershenevich and other scholars began to turn to the sources of Roman law when interpreting the nature and perspectives of the use of fiction ${ }^{7}$. At the same time, these developments were offset after the coup. Thus, the Soviet doctrine perceived fiction as an admission of the legislative technique of bourgeois law. Accordingly, legal fictions could not exist because the law had to be absolute and perfect. However, from the $70 \mathrm{~s}-80$ s, Soviet scholars began to perceive fiction as a legal technique in objective law for the recognition of the absent and vice versa. This legal category has become recognized as established in regulations and applied in practice, a statutory instrument, a special admission to declare true facts or circumstances that did not occur in reality ${ }^{8}$.

In the contemporary theory of law, a position has emerged, according to which the prerequisite for the emergence of legal fictions is the need to regulate public relations by means of "conditionally formulated reality". In fact, fiction emerges as a technical and legal method for recognizing fictitious or invalid judgments, which become generally binding as enshrined in the provision of law ${ }^{10}$. Adopting a legal fiction when drafting a rule of law might show the will of the state regarding justice and be the only possible means to regulate public relations, in order to overcome the situation of ambiguity and double understanding in legal relations, prevent abuse of law by unscrupulous subjects ${ }^{11}$.

In fact, legal fiction could be considered as an admission of rulemaking ${ }^{12}$, legislative technique ${ }^{13}$. It is a matter of technical and legal adherence to which an invalid provision

\footnotetext{
${ }^{7}$ Mejer, D.I. (2003). About legal fictions and assumptions, about hidden and pretended actions. Moscow: Status, pp. 102, 341 [Мейер Д.И. О юридических вымыслах и предположениях, о скрытых и притворных действиях. Москва : Статус, 2003. 426 с.].

${ }^{8}$ Babaev, V.K. (1974). Presumption in Soviet law: tutorial. Gorky: Gorky Higher School of the Ministry of Internal Affairs of the USSR, pp. 28 [Бабаев В.К. Презумпции в советском праве : учебное пособие. Горький : Горьковская высшая школа МВД СССР, 1974. 124 с.].

${ }^{9}$ Ulianovska, O.V. (2009). Fictions in the legal system of Ukraine (Ph.D. abstract), Odessa National Law Academy. Odesa, pp. 6, 13 [Ульяновська О.В. Фікції в правовій системі України : автореф. дис. ... канд. юрид. наук : 12.00 .01 ; Одеська національна юридична академія. Одеса, 2009. 19 с.].

${ }^{10}$ Babaev, V.K. (1974). Presumption in Soviet law: tutorial. Gorky: Gorky Higher School of the Ministry of Internal Affairs of the USSR, pp. 28 [Бабаев В.К. Презумпции в советском праве : учебное пособие. Горький : Горьковская высшая школа МВД СССР, 1974. 124 с.].

${ }^{11}$ Marohin, E.Yu. (2004). Legal fiction in modern Russian legislation (Ph.D. thesis). North Caucasus State Technical University. Stavropol, pp. 159-161 [Марохин Е.Ю. Юридическая фикция в современном российском законодательстве : дисс. ... канд. юрид. наук : 12.00.01 ; Северо-Кавказский государственный технический университет. Ставрополь, 2004. 196 с.].

${ }^{12}$ Kosovych, V.M. (2013). "Legal assumptions" as a means of creating perfect regulatory acts of Ukraine. Scientific Bulletin of Chernivtsi University, issue 644: Jurisprudence, pp. 44-52 [Косович В.М. «Правові припущення» як засіб створення досконалих нормативноправових актів України. Науковий вісник Чернівещького університету. 2013. Вип. 644 : Правознавство. С. 44-52].

${ }^{13}$ Pan'ko, K.K. (2000). Legal fictions in modern Russian law. Problems of legal technology: collection of articles / ed. by V.M. Baranov. Nizhny Novgorod: Nizhny Novgorod Academy of the Ministry of Internal Affairs of the Russian Federation, pp. 459-470 [Панько К.К. Юридические фикции в современном российском праве. Проблемы юридической техники : сборник статей / под ред. В.М. Баранова. Нижний Новгород : Нижегородская академия МВД РФ, 2000. С. 459-470].
} 
is declared valid and becomes binding as a way of securing the rule of law ${ }^{14}$. Thereby, M.A. Pavlova specifies that the conditional declaration of a fact (circumstance) in the fiction is established and real, taking into account relevant circumstances of the case which makes such provisions mandatory ${ }^{15}$. At the same time, the overwhelming majority of scholars, emphasizing the universality of this method of legal technology, point to the possibility of its use in exceptional cases ${ }^{16}$, when other means cannot achieve the goals set by the legislator ${ }^{17}$. That is, legal fictions in the administrative process are to be an exceptional admission of legal technique. In addition, recognizing the circumstances specified in the fiction makes it possible to reduce the amount of evidence-based activity through a simplified procedure for establishing legal facts or composition.

In this case, fictions become links between individual provisions of law and regulatory acts in order to ensure the formal certainty of law, which determines the optimal functioning of the legal system ${ }^{18}$. This means that when implementing procedural discretion, legal fictions chiefly create conditions for establishing and eliminating contradictions or inconsistencies in public relations in their content or form, and contribute to the development of the legal system simultaneously with the renewal of social benefits in the objective reality of the current actual manifestations of the state and society.

\section{Fictions as legal anomalies}

Legal fictions in doctrine refer to legal anomalies. These are atypical regulators of law. Legal fiction allows to change the legal reality (bringing the legal "matter" into a form that does not correspond to it originally). According to A.V. Petrov, an anomaly of law could be considered as random arbitrary deviations in the content of law that do not follow from regular manifestations of the substantive basis of law ${ }^{19}$. O.Ye. Holtsova

${ }^{14}$ Gudz, D.S. (2005). Correlation of legal presumption with related legal categories. Current problems of state and law, issue 25, pp. 109-113 [Гудзь Д.С. Співвідношення правової презумпції зі спорідненими правовими категоріями. Актуальні проблеми держсви і права. 2005. Вип. 25. С. 109-113].

Suprun, T.M. (2013). Legal presumptions and related concepts. Bulletin of the Ministry of Justice of Ukraine, no. 2, pp. 125-132 [Супрун Т.М. Правові презумпції та суміжні поняття. Бюлетень Міністерства юстииї України. 2013. № 2. С. 125-132].

${ }^{15}$ Pavlova, M.A. (2016). The ratio of prejudice to some related categories. Actual problems of native jurisprudence, issue 2, pp. 22-25 [Павлова М.А. Співвідношення преюдиції з деякими суміжними категоріями. Актуальні проблеми вітчизняної юриспруденції. 2016. Вип. 2. С. 22-25].

${ }^{16}$ Tkachuk, O.S. (2015). Fictions in the legal positions of the courts of Ukraine. Scientific Bulletin of Uzhgorod National University. Law series, issue 35(2.1), pp. 200-203 [Ткачук О.С. Фікції у правових позиціях судів України. Науковий вісник Ужгородського національного університету. Серія «Право». 2015. Вип. 35(2.1). С. 200-203].

${ }^{17}$ Ivanskyi, A.Y. (2011). Legal fictions as a legal technique method in the legal regulation of financial relations. Law of Ukraine, no. 3, pp. 236-242 [Іванський А.Й. Правові фікції як прийом юридичної техніки у правовому регулюванні фінансових правовідносин. Право Украӥни. 2011. № 3. С. 236-242].

${ }^{18}$ Alekseev, S.S. (1982). General theory of law: in 2 vol. Moscow: Legal literature. Vol. 2 , pp. 52, 277 [Алексеев С.С. Общая теория права : в 2 т. Москва : Юридическая литература, 1982. T. 2. 286 c.].

${ }^{19}$ Petrov, A.B. (2015). Anomalies of law: concept and nature. Vestnik of Lobachevsky University of Nizhni Novgorod, no. 1, pp. 170-180 [Петров А.В. Аномалии права: понятие 
uses the term "atypical regulators of public relations" to refer to this concept ${ }^{20}$. The researcher considers such regulators of public relations as specific peculiar kinds of rules that are used to regulate public relations in the event of "non-standard" situations ${ }^{21}$. It is worth supporting this opinion and further emphasizing the "non-standard" application of the described legal categories.

On the other hand, H.M. Chuvakova's position regarding the interpretation of these legal categories is that: 1) deviation from the normal development of social relations caused by behaviour that is not provided by law as prohibited, or is not a behaviour at all; 2) a consequence of the presence of gaps in the law; 3) the result of legal conflicts, the inability of the parties due to various subjective factors to independently get out of the conflict state; 4) offences ${ }^{22}$. At the same time, it is difficult to agree with this approach. Legal anomalies cannot, by their very nature, have a negative impact on the practice of law enforcement. Indeed, these categories are subjectively conditioned and have a discretionary nature. Accordingly, there might be differences in the interpretation and use of these categories by individual judges. However, these should be exceptional cases. The task of administrative proceedings, in particular, is to minimize such negative manifestations and constantly promote the coherence of legal positions of the court and the uniformity and consistency of their application.

Scholars have traditionally attributed not only legal presumptions and fictions to legal anomalies, but also legal axioms and pre-emptive legal facts ${ }^{23}$. O.Ye. Holtsova further distinguishes presumptions and fictions as special techniques of legal technique when applying (atypical) legal constructs ${ }^{24}$. It is about the possibility of using such techniques

и природа. Вестник Нижегородского университета имени Н.И. Лобачевского. 2015. № 1. C. $170-180]$.

${ }^{20}$ Holtsova, O.Ye. (2015). Atypical regulators of social relations in the system of social and legal regulation (Ph.D abstract), National Pedagogical Dragomanov University. Kyiv, pp. 1-17 [Гольцова О.Є. Нетипові регулятори суспільних відносин у системі соціальноправового регулювання : автореф. дис. ... канд. юрид. наук : 12.00.01 ; Національний педагогічний університет імені М.П. Драгоманова. Київ, 2015. 17 с.].

${ }^{21}$ Holtsova, O.Ye. (2015). Atypical regulators of social relations in the system of social and legal regulation (Ph.D abstract), National Pedagogical Dragomanov University. Kyiv, pp. 1-17 [Гольцова О.С. Нетипові регулятори суспільних відносин у системі соціальноправового регулювання : автореф. дис. ... канд. юрид. наук : 12.00 .01 ; Національний педагогічний університет імені М.П. Драгоманова. Київ, 2015. 17 с.].

${ }^{22}$ Chuvakova, H.M. (2009). Interpretation of the concept of "legal anomaly". Current problems of state and law, issue 50, pp. 328-334 [Чувакова Г.М. Інтерпретація поняття «правова аномалія». Актуальні проблеми держави і права. 2009. Вип. 50. С. 328-334].

${ }^{23}$ Holtsova, O.Ye. (2015). Atypical regulators of social relations in the system of social and legal regulation (Ph.D abstract), National Pedagogical Dragomanov University. Kyiv, pp. 1-17 [Гольцова О.С. Нетипові регулятори суспільних відносин у системі соціальноправового регулювання : автореф. дис. ... канд. юрид. наук : 12.00.01; Національний педагогічний університет імені М.П. Драгоманова. Київ, 2015. 17 с.].

Petrov, A.B. (2015). Anomalies of law: concept and nature. Vestnik of Lobachevsky University of Nizhni Novgorod, no. 1, pp. 170-180 [Петров А.В. Аномалии права: понятие и природа. Вестник Нижегородского университета имени Н.И. Лобачевского. 2015. № 1. С. 170-180].

${ }^{24}$ Holtsova, O.Ye. (2015). Atypical regulators of social relations in the system of social and legal regulation (Ph.D abstract), National Pedagogical Dragomanov University. Kyiv, pp. 1-17 [Гольцова О.Є. Нетипові регулятори суспільних відносин у системі соціально- 
to maintain the consistency of the court's legal positions regarding the qualification of the facts of the case and the interpretation of the rules of law, the resolution of conflicts, the elimination of gaps in legal regulation, etc.

It is worth considering in more detail the characteristics of the key types of legal anomalies regarding their influence on the exercise of procedural discretion in administrative proceedings. In particular, fiction is necessary for law because it is a source of generalization to individual regulations ${ }^{25}$. According to R.V. Sabodash, it is possible to use the theory of fiction to refer to "imaginary entities"26. As I.P. Zelenko explains, the main tendency to use fictions in the New time was the transition to the technology of procedural regulation in order to save the means of proof ${ }^{27}$. According to V.M. Bevzenko, legal fictions in the administrative procedural law of Ukraine are placed in the provisions of the national administrative procedural legislation, philosophical and logical, complex concepts, categories, constructions and facts that give effect to such legislation, ensure its effectiveness and fulfilment of the basic tasks, protection, renewal, recognition of subjective rights, freedoms, legitimate interests of public content ${ }^{28}$. It is often advisable to use legal fiction when considering and resolving disputes, provided that there are false or clearly erroneous judgments in the provisions of existing applicable legal rules. As a consequence, time and resource costs for clarifying the facts of the case and overmotivating the judgment are minimized.

In foreign doctrine, legal fictions are viewed in the context of "as if" reasoning, which promotes the application of legal rules to new circumstances by means of analogues and arguments of equivalence ${ }^{29}$. L.L. Fuller defines legal fiction as a statement with full or partial awareness of its fallacy, or a false statement that is found to be useful, in other words, a statement which the judge knows is erroneous but uses it as $\operatorname{such}^{30}$. J. Camden, $\mathrm{K}$. Fort interpret legal fictions as the type of narrative by which fictional perfect law is created $^{31}$. Legal fictions are created by a judge for convenience, to ensure the continued

правового регулювання : автореф. дис. ... канд. юрид. наук : 12.00.01 ; Національний педагогічний університет імені М.П. Драгоманова. Київ, 2015. 17 с.].

${ }^{25}$ Mejer, D.I. (2003). About legal fictions and assumptions, about hidden and pretended actions. Moscow: Status, pp. 102, 341 [Мейер Д.И. О юридических вымыслах и предположениях, о скрытых и притворных действиях. Москва : Статус, 2003. 426 с.].

${ }^{26}$ Sabodash, R.V. (2011). Essays on public legal entities. Bulletin of economic litigation, no. 2, pp. 127-130 [Сабодаш Р.В. Нариси про юридичних осіб публічного права. Вісник господарського судочинства. 2011. № 2. С. 127-130].

${ }^{27}$ Zelenko, I.P. (2014). Concept and meaning of the legal fiction as a legal and social tool. Scientific Bulletin of Kherson State University. Legal Sciences Series, issue 6-1, vol. 1, pp. 32-35 [Зеленко І.П. Поняття та значення юридичної фікції як правового та соціального інструменту. Науковий вісник Херсонського державного університету. Серія «Юридичні науки». 2014. Вип. 6-1. Т. 1. С. 32-35].

${ }^{28}$ Bevzenko, V.M. (2012). Fictions in the administrative process and administrative procedural law of Ukraine. Administrative law and process, nо. 2(2), pp. 99-108 [Бевзенко B.M. Фікції в адміністративному процесі й адміністративному процесуальному праві України. Адміністративне право і прощес. 2012. № 2(2). С. 99-108].

${ }^{29}$ Knauer, N. (2010). Legal Fictions and Juristic Truth. St. Thomas Law Review, vol. 23, pp. $70-120$.

${ }^{30}$ Fuller, L.L. (1967). Legal Fictions. Stanford: Stanford University Press, pp. 9 (158 p.).

${ }^{31}$ Camden, J., Fort, K.E. (2008). "Channeling Thought": The Legacy of Legal Fictions from 1823. Am. Indian L. Rev., vol. 33, no. 1, pp. 77-109. 
smooth application of the rule of law. At the same time, the questioning of legal fictions could cast doubt on the assumptions of judges and other legal professionals about the impact of these assumptions externally. This includes cases where legal fictions are no longer considered fictions, in particular, by knowledgeable persons who trace the impact of this "slippage" to law enforcement ${ }^{32}$. That is, fiction is in line with the rule of law and justifies the actions of the court.

\section{Application of legal fictions in the administrative process taking into account the theory of Grundnorm}

H. Kelsen's Grundnorm could be considered as one of significant theoretical prerequisites for the use of legal fictions in the administrative process. In particular, Grundnorm in the Kelsen system does not contain factual prerequisites, as envisaged in the concept of Kantian transcendental understanding ${ }^{33}$, but is essentially a transcendental category, at least containing factual components that might be either actually true or in fact erroneous ${ }^{34}$. At the same time, the assumption of existence of something that cannot exist only partially justifies the expediency of using such a "fictional" category. As a consequence, this is an assumption, not the actual existence of Grundnorm truth, which seems somewhat metaphorical. This sets it apart from the Hart derivative of the ultimate recognition rule. It is appropriate to understand fiction not so much as an assumption (or a transcendent understanding) whose actual truth is irrelevant, but as a statement that is literally false but not literally wrong in essence. Otherwise, this category would be a "mistake" rather than a "fiction". Then the fictitious use of the "legal fiction" to denote H. Kelsen's idea of Grundnorm is fictitious.

Thus, the premise of an argument could usually be presented in a hypothetical form. In the theory and philosophy of law, the idea of assuming something for the sake of an argument or with the assumption of the truth of one sentence is often applied in order to understand some other judgment. In this case, there might be assumptions or hypotheses about a particular fact for the corresponding argument in circumstances in which it does not matter or the omitted fact is true or false. Although the actual fact of the case is irrelevant, the existence of a fact is allowed, since the assumption adds clarity to the perception of the specific circumstances of the case. As a result, the connection between legal fictions and legal regulations is revealed. Since judges are primarily required to justify such deviations from the rules, they resort to appropriate exculpatory manoeuvres to avoid simply claiming that they do not comply with the rules. One of these manoeuvres, although hardly the only one, is a type of legal fiction, a reinterpretation of the facts of an event in order to make these facts compatible with the rule, and at the same time allowing to get the correct result. This is a type

${ }^{32}$ Camden, J., Fort, K.E. (2008). "Channeling Thought”: The Legacy of Legal Fictions from 1823. Am. Indian L. Rev., vol. 33, no. 1, pp. 77-109.

${ }^{33}$ Paulson, S. (1992). The Neo-Kantian Dimension of Kelsen's Pure Theory of Law. Oxford Journal of Legal Studies, vol. 12, pp. 311-332.

Raz, J. (1979). Kelsen's Theory of the Basic Norm. The Authority of Law: Essays on Law and Morality / ed. by J. Raz. Oxford: Clarendon Press, pp. 122-145.

${ }^{34}$ Schauer, F. (2011). Legal Fictions Revisited. Virginia Public Law and Legal Theory Research Paper, no. 2011-29, pp. 1-30. 
of legal fiction-reinterpreting $\mathrm{X}$ (or class $\mathrm{X}$ ) as $\mathrm{Y}$ in order to avoid an "inconvenient", unreliable, false, etc. result for the purposes of the law. As a rule, it is recognized that $\mathrm{X}$ is not $\mathrm{Y}$. That is, the court considers the creation of a fiction as a legitimate action within the framework of the judicial process; the activity that could be performed without concealment as a discretely true category.

According to H. Kelsen, Grundnorm differs from the Weiginger hypothesis, since the invented judgment is formed with the awareness that it does not correspond to reality ${ }^{35}$. If actually true - if an understanding of the legal system requires an understanding that accidentally reveals reality, then it would be strange to describe such an understanding as a fiction. At the same time, if the understanding does not correspond to reality, or, more precisely, it simply does not matter whether it is true or not, then H. Kelsen describes this understanding of Grundnorm as a fiction. Thus, this is an unpredictable untruth, and even more - the irrelevance of the actual truth or the falseness of Grundnorm, which explains why it is usually considered a legal fiction in Kelsen's theory of law ${ }^{36}$.

The doctrine recognizes that fictions could be contained in legal rules ${ }^{37}$. At the same time, as O.A. Kursova specifies, legal fictions are much less common than, for example, legal presumptions to be indirectly expressed in the provisions of law ${ }^{38}$. As a general rule, legal fictions are fixed in hypotheses and dispositions of legal regulations regarding the proof of lawfulness of actions, establishment of legal facts and syllables, recognition of subjective powers, etc. Thus, within the administrative process, the fiction might conditionally replace unknown circumstances in the context of the consolidation of legal facts. These are alternative ways of filling the "gaps" of proof, such as the artificial equation of different or opposite circumstances, an indication of the validity of invalid circumstances and vice versa, a promising establishment of the circumstances of the case before they actually appear or occur later than in reality, "reconstruction" of real legal facts that have happened and passed, and others.

\section{Case law on the application of legal fictions}

Types of fictions in the administrative process could be related to the establishment or recognition of legal facts. Thus, the fictions established by the competent authorities are fixed in the relevant regulatory and administrative acts, planning acts and other law enforcement acts. As a general rule, such acts extend to certain persons, and might continue to be applied with a preliminary ruling to the settlement of disputes involving the same persons.

\footnotetext{
${ }^{35}$ Schauer, F. (2011). Legal Fictions Revisited. Virginia Public Law and Legal Theory Research Paper, no. 2011-29, pp. 1-30.

${ }^{36}$ Kelsen, H. (1991). General Theory of Norms / transl. M. Hartney. Oxford: Clarendon Press, pp. 256 (518 p.).

${ }^{37}$ Ulianovska, O.V. (2009). Fictions in the legal system of Ukraine (Ph.D. abstract), Odessa National Law Academy. Odesa, pp. 6, 13 [Ульяновська О.В. Фікції в правовій системі України : автореф. дис. ... канд. юрид. наук : 12.00 .01 ; Одеська національна юридична академія. Одеса, 2009. 19 с.].

${ }^{38}$ Kursova, O.A. (2001). Fictions in Russian law (Ph.D. abstract), Nizhny Novgorod Academy of the Ministry Internal Affairs of the Russian Federation. Nizhny Novgorod, pp. 6 [Курсова О.А. Фикции в российском праве : автореф. дисс. ... канд. юрид. наук : 12.00.01 ; Нижегородская академия Министерства внутренних дел Российской Федерации. Нижний Новгород, 2001. 23 с.].
} 
For example, the Supreme Court composed of judges from the Cassation Administrative Court used a legal fiction to maintain the legal status of victims of Chornobyl catastrophe of category 4 after exclusion on the basis of the law of the zone of enhanced radiological control as one of the zones of radioactively contaminated territories. The court of cassation decided that the exception from January 1, 2015 zone of enhanced radiological control from the list of radioactively contaminated areas does not deprive of the status of victim of persons who had previously set the status to issued and the identity of the victim owing to Chornobyl accident. A person who has been issued an indefinite certificate of a citizen who has permanently resided in the zone of enhanced radiological control (category 4) is considered a victim of the Chornobyl catastrophe $^{39}$. The Cassation Administrative Court of the Supreme Court emphasized that the status of the victim of the Chornobyl catastrophe is indefinite. Therefore, the exclusion of the zone of enhanced radioecological control does not deprive a person of the status of a victim of the Chornobyl catastrophe, taking into account the legality of acquiring such a status and the absence of legal grounds for its termination. The described fiction could not be applied exclusively in the case of fixing the direct rule of the law on the invalidity of previously issued certificates of category 4 to persons who are victims as a result of the Chornobyl catastrophe.

When determining whether it is possible to apply legal fictions in the consideration and resolution of administrative cases, it is necessary to consistently focus on a set of the following prerequisites: 1) expediency; 2) whether such a legal category already exists; 3 ) whether such implementation will contribute to achieving the goals and objectives of administrative proceedings; 4) whether this is the only possible way to establish justice. In fact, legal fictions allow us to conditionally recognize the truth by fixing it in the provision of law. At the same time, unlike presumptions, fictions do not show the legally enforced normal state of law and $\operatorname{order}^{40}$. Legal fictions are essentially irrefutable imaginary judgments with a pragmatic purpose and imperative action. Instead, legal presumptions could be both imperative and dispositive refutable assumptions - true in probability.

When considering and resolving administrative cases, fictions could be classified into subspecies depending on the subject of generalization and refutation. The way

\footnotetext{
${ }^{39}$ Supreme Court (2019). Resolution of the Supreme Court in the case № 287/25/17-a dated ofJanuary23,2019.Retrievedfrom:http:/www.reyestr.court.gov.ua/Review/79349466[Постанова Верховного Суду від 23 січня 2019 року у справі № 287/25/17-a. URL: http://www.reyestr. court.gov.ua/Review/79349466 (дата звернення: 09.02.2020)].

Supreme Court (2019). Resolution of the Supreme Court in the case № 697/121/17 dated of March 20, 2019. Retrieved from: http://www.reyestr.court.gov.ua/Review/80632873 [Постанова Верховного Суду від 20 березня 2019 року у справі № 697/121/17. URL: http:// www.reyestr.court.gov.ua/Review/80632873 (дата звернення: 09.02.2020)].

Supreme Court (2019). Resolution of the Supreme Court in the case № 357/8174/17 dated of May 15, 2019. Retrieved from: http://www.reyestr.court.gov.ua/Review/81759314 [Постанова Верховного Суду від 15 травня 2019 року у справі № 357/8174/17. URL: http:// www.reyestr.court.gov.ua/Review/81759314 (дата звернення: 09.02.2020)].

${ }^{40}$ Zozul, I.V. (2013). Presumptions in the administrative law of Ukraine (Ph.D. abstract), National Aviation University. Kyiv, pp. 8, 9 [Зозуль I.В. Презумпції в адміністративному праві України : автореф. дис. ... канд. юрид. наук : 12.00 .07 ; Національний авіаційний університет. Київ, 2013. 19 с.].
} 
O.V. Ulianovska explains, by the refutation of imaginary legal structures, the fiction is constructive as a product of abstract thinking, perceived by the legal doctrine and / or enshrined in law in the form of a legal regulation, an institution of law, used to fill a gap in law. Destructive is a fiction that is not perceived by the legal doctrine and, although it could be established in the provision of law, but confirms the illegality of the interest, which leads to the spread of such a legal construction ${ }^{41}$. It is worth emphasizing that the described approach might also apply to those fictions that are not legally regulated, but were, in particular, the descriptive or motivational part of the court decision has been formulated in when considering and resolving the case.

The subject of legal fiction might be primary and conditional. Thus, the first one refers to the phenomena of objective reality in order to summarize the circumstances of life of the state and society, regardless of the existence of appropriate legal regulation. For example, to establish a person's legal status, statute of limitations, renewal of procedural time limits, etc. Among the conditioned fictions, we could distinguish those that simplify the course of actual social relations through their connection with legal activities. For the justice sector, it is particularly important to form a simple and optimal law enforcement practice based on such fictions. In particular, the recognition of rights to public property, information, establishment or confirmation of the legal regime of information with an appropriate level of access, including the activities of accusers, and the like.

It is necessary to assume that the judge's professional activity in the exercise of procedural discretion provides for the possibility of algorithmization of the process of creating, electing or changing the appropriate non-standard regulators. It might make sense to refer to the theory of search and merge algorithms. In particular, the searchaggregation algorithm is associated with the elimination of extraneous factors in order of decreasing influence, taking into account combinatorial search capabilities within a forward-looking approach ${ }^{42}$. When referring to the algorithm of the plurality of discontinuities, it is permissible to determine the minimum number of restrictive conditions to be cut off in order to achieve a valid result $t^{43}$.

The criteria for the validity of recourse to legal presumptions or fictions are the verbal baseline and the definition of the "appropriate" meaning of words (through open questions $)^{44}$. Thus, fictions within the limits of formal legitimacy allow filling "gaps" as

${ }^{41}$ Ulianovska, O.V. (2009). The essence of legal fiction. Current problems of state and law, issue 51, pp. 459-463 [Ульяновська О.В. Сутність правової фікції. Актуальні проблеми держави і права. 2009. Вип. 51. С. 459-463].

${ }^{42}$ Skiena, S. (2011). Algorithms. Development guide (transl. from English). $2^{\text {nd }}$ ed. Saint Petersburg: BHV-Peterburg, pp. 258, 259, 262, 264, 267, 572-573 [Скиена С. Алгоритмы. Руководство по разработке. Пер. с англ. 2-е изд. Санкт-Петербург : БХВ-Петербург, 2011. 720 c.].

${ }^{43}$ Skiena, S. (2011). Algorithms. Development guide (transl. from English). $2^{\text {nd }}$ ed. Saint Petersburg: BHV-Peterburg, pp. 258, 259, 262, 264, 267, 572-573 [Скиена С. Алгоритмы. Руководство по разработке. Пер. с англ. 2-е изд. Санкт-Петербург : БХВ-Петербург, 2011. 720 c.].

${ }^{44}$ Tsyppelius, R. (2016). Methods of law enforcement (transl. from German). Kyiv: Iustinian, pp. 81, 107 [Циппеліус Р. Методика правозастосування. Пер. 3 нім. Київ : Юстініан, 2016. 192 c.]. 
a material source of discretion in the absence of a legal regulation (provided that there is no rule of law and precedent for interpreting beyond the normative content in the way of filling in the gaps in accordance with the natural principles of equity, liberty, justice, and general principles of the rule of law $)^{45}$.

Thus, fiction is to bring actual social relations into a legitimate form of implementation, which is not initially in line with the current state of legal reality. It should be clarified that in the contemporary development of the doctrine and practice of procedural discretion, the term "anomalies of law" is more appropriate. As a result of the implementation of the concept of procedural discretion, it will be possible to talk about obtaining by the legal fictions of the status of atypical regulators in the administrative process.

\section{Conclusions}

Thus, the following features of legal fictions could be distinguished, in particular, for achieving the goals and objectives of administrative proceedings:

- primary indistinctness or absence, conflict of legal regulation of public relations;

- limited use regarding the social and legal context of actual public relations to which the unconditional effect of fictions applies;

- non-alternative creation of invalid, imaginary legal structures in legal reality;

- cogency (complexity);

- hierarchy according to the degree of complexity of fictions that can consistently cause each other, recursively determine self-similarity.

It is possible to classify arguments, methods and approaches to the application of such atypical regulators in the administrative process by the "meta" degree:

1) on the fundamental metric - internal, or zero-order arguments. The context of the situation is used, the problem is solved by the proposed methods within a certain sphere. For example, completing the model's canons to get rid of the (imaginary?) errors of the author or explain an important point. As a sample we can also call the solution of a mathematical problem mathematical methods;

2) at the derivative definitive level - by defining the concepts:

- functional ( $\mathrm{X}$ and $\mathrm{Y}$ are $\mathrm{Z}$ if $\mathrm{f}(\mathrm{X})=\mathrm{C}$ and $\mathrm{f}(\mathrm{Y})=\mathrm{C}$; that is, two categories correspond to the same definition, if they perform the same function, they also interact under certain conditions);

- structural ( $\mathrm{X}$ and $\mathrm{Y}$ are $\mathrm{Z}$ if $\mathrm{X}$ is a composition of $\mathrm{f}$ and $\mathrm{g}$; that is, two categories correspond to the same definition if they have a common structural element);

- relative ( $\mathrm{X}$ and $\mathrm{Y}$ are $\mathrm{Z}$, because they are in relation to $\mathrm{f}$ with a set of objects $\mathrm{E}$; that is, two categories correspond to the same definition, if they occupy the same place, in the general definition of the word "place", they correspond to the same set of coordinates).

${ }^{45}$ Barak, A. (1999). Judicial discretion (transl. from English). Moscow: NORMA, pp. 111, 309 [Барак А. Судейское усмотрение. Пер. с англ. Москва : НОРМА, 1999. 376 с.]. 


\title{
ПРАВОВІ ФІКЦІЇ ДЛЯ АДМІНІСТРАТИВНИХ СУДІВ
}

\author{
Анна Барікова, \\ Правове управління (I) департаменту аналітичної \\ та правової роботи Верховного Суду, \\ головний спеціаліст \\ Національна академія внутрішніх справ, викладач, \\ кандидат юридичних наук \\ orcid.org/0000-0002-9707-0106 \\ anna.barikova@gmail.com
}

\begin{abstract}
Мета. Стаття розкриває особливості застосування адміністративно-процесуальних правових фікцій із метою уникнення зловжсивання правом та ухилення від виконання закону під час здійснення прочесуального розсуду.
\end{abstract}

Методи. Для досягнення иілей дослідження автор використовує спеціально-юридичні методи наукового пізнання: формально-логічний, системно-функиіональний, формально-логічний, порівняльно-правовий.

Результати. Розглянуто історіографію застосування правових фікцій. У статті висвітлено сутність фікиій як правових аномалій. Деталізовано застосування правових фікцій в адміністративному прочесі з урахуванням теорії Grundnorm.

Виявлено зв'язок між юридичними фікиіями та правовими нормами. Юридичні фікиії описано як переосмислення фактів події, щоб зробити иі факти сумісними з правилом, водночас дозволяючи одержсати правильний результат. Ідеться про тип юридичної фікиії - переосмислення $X$ (або класу X) як Y, щуоб уникнути «незручного», недостовірного, хибного та іншого результату для иілей закону. Як правило, визнається, щэо Х не є Ү. Тобто суд розглядає створення фікиії як законну дію в межах судового прочесу, а діяльність, щзо може виконуватися, - без приховування як дискретно істинну категорію.

Описано судову практику щуодо застосування правових фікиій. Запропоновано, щуо правові фікиії в адміністративному прочесі мають бути винятковим прийомом юридичної техніки. Продемонстровано такі альтернативні напрями заповнення «прогалин» доказування, як штучне прирівнювання різних чи протилежсни обставин, вказівка на дійсність нечинних обставин, і навпаки, перспективне встановлення обставин справи до їх фактичної появи або виникнення пізніше, ніж насправді, «реконструкиія» реальних юридичних фактів і складів, які відбувалися та минули, тощь. До того ж визнання вказаних у фікції обставин вірогідними дає змогу зменшити обсяг діяльності з доказування завдяки спрощеному порядку встановлення юридичних фактів чи складів.

Висновки. По-перше, виокремлено ознаки правових фікиій, зокрема, для досягнення мети й завдань адміністративного судочинства. По-друге, запропоновано класифікацію аргументів, методик $і$ підходів до застосування вказаних нетипових регуляторів в адміністративному процесі за ступенем «мета-» на певні типи, зокрема: 1) на фундаментальному метарівні внутрішні аргументи, або аргументи нульового порядку; 2) на похідному дефінітивному рівні щчодо визначення функціональних, структурних і відносних понять.

Ключові слова: правовий механізм, інструменти, аномалії у праві, нетипові регулятори, правові фікції, процесуальний розсуд. 